DOI: 10.14526/2070-4798-2020-15-1-76-81

\title{
Psychophysical readiness to physical activity. From external requirement to personality need
}

\author{
Vera S. Makeeva ${ }^{*}$, Galina A. Yamaletdinova ${ }^{2}$, Kseniya E. Bruy ${ }^{3}$ \\ ${ }^{1}$ Russian State University of Physical Culture, Sport, Youth and Tourism \\ Moscow, Russia \\ ORCID: OOOO-OOO1-5969-4324, vera 191@mail.ru \\ ${ }^{2}$ Liberal Arts University \\ Yekaterinburg, Russia \\ ORCID: OOOO-OOO2-4697-422, yamalga@mail.ru \\ ${ }^{3}$ Moscow Region State University \\ Moscow, Russia \\ ORCID: oooo-0002-0045-063X, ksenia tokareva199o@mail.ru
}

\begin{abstract}
The article deals with the issues of the students preparation for physical activity and sport mainly through the transformation of motives to be engaged in P.E. from the university's requirement to the personality need. Introduction. Also it is revealed that formation of physical qualities, psychic abilities and skills for health promotion are necessary to support healthy way of life and to prevent some professionally dangerous diseases. Materials and methods. In this project we showed how students learn to determine abilities and capabilities, advantages and disadvantages on the basis of assessment and self-assessment of their organism functional state and professionally important traits of the character. At each next stage of preparation, the competence and skills for physical and physical conditions regulation were developed and the elimination methods of health deviations were searched in order to transfer ones to the professional sphere and life activity. Results. By the end of the study, the programs of selfdevelopment and self-improvement were defined, transfer of the valuable relation to physical activity in the process of interaction with other people was carried out, and as a result, the positive dynamics of life quality had defined.
\end{abstract}

Keywords: physical activity, motives, self-assessment, health, self-regulation, skills.

For citations: Vera S. Makeeva*, Galina A. Yamaletdinova, Kseniya E. Bruy. Psychophysical readiness to physical activity. From external requirement to personality need. Russian Journal of Physical Education and Sport. 2020; 15(1): 64-68. DOI: 10.14526/2070-4798-2020-15-1-76-81

\section{INTRODUCTION}

Today, to identify the individual ego is a feature of social relations in the today's Russian society, as a counter to the slogan of Soviet period aimed to community ego. Therefore, choosing pedagogical methods of interaction, one should take into account certain individual characteristics: age, gender, motives, social class, profession, etc. [1-9]. In turn, the sustainability of society depends on the prudent human nature, the full realization of the potentialities, concluded in the organic intellectual, emotional and psychophysical unity. And each student must have the techniques and methods, which contribute to the formation of proper qualities, properties and conditions, manifested in intelligence, health, knowledge, quality, productive work and active life [10-15]. In this regard, the implementation of consistent actualization of professional and personal development through various forms of human activity has become particularly important.

The purpose of the study is to develop a complex of psychophysical qualities and skills for physical activity, on the bases of the positive hereditary factors, within the educational area of physical culture.

\section{MATERIALS AND METHODS}

Training sessions were conducted in the form of lectures, practical, individual and independent classes. Teachers reported to students some information about:

- $\quad$ psychophysical conditions, health criteria and methods for assessing its dynamics; 
- $\quad$ nature of physical activity and its impact on human behavior;

interaction features and methods of the acquired skills transfer in the professional communication;

- methods of maintaining motor activity, practical use of exercise systems, methods and options for self-management and self-action;

- motivation and transfer of value attitude to physical training in the practice of future professional activity.

Research included diagnostic, analytical, motivational and value, designing stages.

At the diagnostic stage, students measured integral component of the psychophysical state, that included cardiovascular system and respiratory function indicators, physical development and individual intellectual characteristics. Cardiovascular system was researched by means of heart rate, arterial pressure, pulse pressure, minute blood volume indicators and other simple functional tests [4]. Also, the respiratory system reserves were studied by students. In particular, they determined the reserves of oxygen in the body, vital capacity of the lungs, inspiratory breath-holding (test Shtange), holding the breath when you exhale (test Genchi). The methods by which physical development was studied include: measurement of the size and weight (somatometry), inspection and description of symptoms and physique body and appearance (somatoskopiya), method of indices (body mass index, life index, indicator of Pinie, etc.), method of standards and anthropometric profiles [4]. Psychophysical qualities, abilities and skills were diagnosed according to the tests named "black-andred table" and "compasses", "reaction time to the visual signal and reactions to the moving object".

All that tests made it possible to determine attention, memory, reproductive and spatial thinking, mobility of mental processes, sensitivity thresholds of the visual analyzer, coordination of fine movements. In the pedagogical process, priority was given to samples and tests. They do not require the participation of qualified personnel, test simulators and sophisticated equipment. They identified the dynamics of functional body stability in a complex way. Thus, the measured integral component of psychophysical state was available for every student.

At the second analytical stage of the study, the main goal was to form the foundations of selfknowledge (the process of determining one's abilities and capabilities, one's strengths and weaknesses). Students were trained in monitoring and selfcontrol for physical state and development, during educational practical lessons under the guidance of teaching staff. This process formed the attitude to active, conscious and purposeful self-improvement, increased interest in physical exercises, changed the real attitude to physical culture.

Students carried out the analysis of the psycho-physical conditions development. The relationship of measured indicators showed to students some peculiarities of their functional state, physical development of the body, and intellectual personality characteristics. They could determine the latent functional lack of systems, its degree, the state of regulatory mechanisms, adaptive and compensatory reactions to a specific physical effort. Thus, the ability and skills to determine psychophysiological status contributed to the readiness for professional activities and life in general [5].

The training in creating a program of self-improvement, its realization and evaluating effectiveness was the main goal at the third motivational and value stage. Skills of healthy living were provided by pedagogical situations in the educational process, a purposeful statement of tasks, organization of practical activity, taking into account individual features and abilities of students. Positive advances in physical activity of students relied on methods of exerting influence, formation of skills to adequately assess themselves, the reflection of their activities and their behavior, the ability to draw objective conclusions. Replenishment of knowledge, abilities and skills for purposeful formation and management of own functional state and motor activity was carried out by means of: relaxation methods, psychotechnical games; the form of poster methods; recommendations on the use of individual physical effort and level of health.

Students explored methods to eliminate deviations from the optimal level of psychophysical 
state, and as a result, a program of self-development and self-improvement was formed. Students independently created a personal project of a healthy lifestyle, during their chosen practical course and self-studies. Thus, the skills of self-control and skills to determine the effectiveness of the means, methods, organization forms, the valuable attitude to physical activity were formed.

At the fourth stage, some special relations between teacher and students were created in the process of performing physical exercises, which contributed to cooperation, mutual trust, dialogue. Attention was focused on self-control, self-correction and self-education as a result of self-improvement. The use of this experience in the process of physical self-improvement in several activities, the formation of self-regulation skills and individual psychotechnics contributed to the fact that students acted as a subject of self-educational activities. The mindset to subjective transformation of the information was carried out in the following ways: given reception (standard) - method of its execution, enriched personal meaning, on the basis of which the process of solving the problem was recognized from past experience.

Self-control of students and assessment of their own achievements in the development of motor actions was carried out as follows: $\mathrm{O}-\mathrm{a}$ task was not completed; 1 - "anyone could do this" 2 "majority could do this"; 3 - "some people could do this"; 4 - "only one person could do this". This approach provided planning, control, correction and assessment of their own performance by students.

On the basis of the data obtained, the search for methods to transfer the personal value attitude to physical activity to another environment, in particular, to the process of interaction with other people during the pedagogical practice was carried out. After graduation, students rated " 4 - only one person could do this", were transferred to the group of sports improvement, and then received a certificate of additional pedagogical education in the specialty "physical culture - sports club leader".

Participants included students 18-22 years old, who studied at different universities. Pedagogical experiment was conducted in the period from 2015 to 2018.

\section{RESULTS AND DISCUSSION}

Daily educational, industrial and household activities make high demands on the human body. The effectiveness of the functional regulation system, which is carried out in different living conditions, is also determined by the level of the body compensatory capabilities. The results of the experiment showed that students could independently and quickly identify the initial signs of the homeostasis regulatory mechanisms violation due to fatigue or violation of the adaptation regime and to establish their impact on the effectiveness of educational and professional activities. Thus, students could identify the nature of the body and health adaptive reactions, the body's resistance to physical stress, adaptation to the climatic conditions of the region, to search for methods and means of recovery through their own educational and scientific research and based on the analysis of theoretical sources.

The information in the table objectively reflects psychophysical readiness to physical activity, shows which parameters are developing more intensively, and which are more difficult. This figure reflects the impact of a streamlined process of physical self-improvement to optimal preparation of students for occupation and formation of a social attitude to the physical self-education.

The students `experience of participation in the evaluation of psychophysical conditions, as a result of pedagogical influence, contributed to the expansion of the personal needs, desires, feelings awareness scope. They are coded in different physical states, prepare for a realistic resolution of internal conflicts, from the restructuring of the cognitive sphere. A meaningful analysis of their psychophysical conditions led to a deeper perception and transforming information and scientific knowledge into knowledge for decisionmaking. This increases the ability to understand and change the structure of motor activity: from external requirement ('I want passing my exams, that's why I have to engage obligatory physical education classes") to personality need and mobilization efforts ("I want to be healthy, that's why I need knowledge, skills and abilities to improve in physical education 
myself. By the way it can be helpful for other people transfer lessons learned") $[6,7,8]$. and should find means to interact with others to

Table 1 - Dynamics of students psychophysical condition during pedagogical experiment

\begin{tabular}{|c|c|c|}
\hline Indicators & $\begin{array}{c}\text { At the } \\
\text { beginning of } \\
\text { experiment }\end{array}$ & $\begin{array}{c}\text { At the end of } \\
\text { experiment }\end{array}$ \\
\hline Physical freedom (points) & $2,28 \pm 0,9$ & $9,08 \pm 1,3$ \\
\hline Possession method for physical actions (points) & $3,29 \pm 1,9$ & $7,91 \pm 1,5$ \\
\hline $\begin{array}{c}\text { Motor means of expression: body language, facial expressions, } \\
\text { postures (points) }\end{array}$ & $3,08 \pm 0,9$ & $9,11 \pm 1,8$ \\
\hline Emotional flexibility (points) & $2,01 \pm 1,9$ & $8,21 \pm 1,5$ \\
\hline Communicative skills and self-reflection (points) & $4,22 \pm 2,9$ & $8,71 \pm 1,4$ \\
\hline Dance and creative movement (points) & $3,1 \pm 0,9$ & $7,21 \pm 1,5$ \\
\hline Verbal memory (word count) & $7,12 \pm 0,3$ & ${ }^{*} 8,21 \pm 0,7$ \\
\hline Numbers memory (numbers count) & $4,53 \pm 1,2$ & ${ }^{*} 5,43 \pm 0,6$ \\
\hline Attention span (quantity of looked through signs) & $1602 \pm 24$ & ${ }^{*} 1593 \pm 31,6$ \\
\hline The focus (number of errors) & $2,0 \pm 1,7$ & $0,4 \pm 0,7$ \\
\hline
\end{tabular}

Note: ${ }^{*}$ - no statistically significant difference

During the pedagogical practice, students carried out the transfer of experience, they created a general positive emotional attitude and focused on motor activity as a method of management of psychophysical conditions in order to improve performance and health. Following the logic of Collins, [1] the fulfillment of these conditions triggers a ritual of interaction and promotes group solidarity. A belonging to a group becomes valuable, emotionally colored and acts as a goal of group morality and ultimately contributes to the accumulation of emotional energy in the person (student). It is reflected in the ability and skill of professional activity to engage in interaction with a sense of confidence and enthusiasm [1]. Physiologically, this is described as "... the human nervous system's mood for rhythmic involvement in interaction with other people" [1].

In turn, the state of health and well-being characterizes the quality of human life, and together with the success in professional activities reduces the cost of adaptation and the risks of diseases. All this makes it possible to improve the social status and the individual ability to make a choice in the social, political and economic spheres of society that affects the welfare of the whole country $[2,6,16]$.

\section{CONCLUSION}

Thus, an active and positive attitude to physical activity is manifested in active measures and it serves as a value of the individual internal position in the free decision-making. It is in this context that health relevance is the need or interest or purpose in relation with benefit and greater good of the world $[9,10$. This position is revealed in such type of behavior, which is self-preservation, health-saving and conforms to a healthy lifestyle. It permits to identify and develop all the healthy trends, to actualize the resource potential, to design individual life programs, to ensure the growth of health potential in the unity of all its components.

\section{REFERENCES}

1. Klimenkov G.V., Afanas'ev V.G., Ofrihter E.G., Berg M.D. Universal approach to the analysis of health factors and risks to human health. Materialy 4oj Sibirskogo Fiziologicheskogo kongressa [Materials of the 4th Siberian Physiological Congress]. Novosibirsk: In-t Physiology CO RAMN. 2002: 45-46 [In Russ.].

2. Makeeva V.S. Formation of common interests and physical culture of students on the basis of a differentiated approach. Vestnik Luganskogo nacional'nogo universiteta Tarasa Shevchenko (pedagogicheskie nauki). 2013; 8(267): 107-114. [In Russ.].

3. 3. Makeeva V.S., Osipenko E.V. Teoreticheskie aspekty i prakticheskie metodiki $v$ monitoringe psihofizicheskogo sostoyaniya 
shkol'nikov $i$ studentov: uchebnoe posobie [Theoretical aspects and practical methods in monitoring the psychophysical state of schoolchildren and students: textbook]. Ministry of Education and Science of the Russian Federation, State University UNPC, Gomel State Department named after F. Skorina. Smolensk: LLC-PrintExpress. 2015: 146-174 [In Russ.].

4. MakeevaV.S. Professional'nolichnostnoe razvitie studenta $v$ obrazovatel'nom prostranstve fizicheskoj kul'tury: monografiya [Professional and personal development of a student in the educational space of physical culture: monograph]. Orel: FGBOU VPO "GosuniversitetUNPK. 2014: 235 [In Russ.].

5. Makeeva V.S., Polyakov D.O., Pushkina V.N. Tourism in the formation of professionally significant personal qualities of students in the field of physical culture. Rossijskij psihologicheskij zhurnal. 2015; 12(4): 46-54 [In Russ.].

6. Prozorova YU.A. R. Collins ' theory of interactive rituals: From microinteraction to macrostructure. Zhurnal sociologii I social'noj antroplogii . 2007; X(1): 57-73 [In Russ.].

7. Pytkin A.N. Klimenkov G.V. Quality of life, health and welfare from the perspective of human potential and human capital. Vtstnik UGAES. Nauka. Obrazovanie. Ekonomika. Seriya: Ekonomika. 2012; 1(1): 35-43 [In Russ.].

8. Yur'eva M.N. Personal and professional development of a choreographer student at a University: an integrative resource approach. Professionalism of the individual in educational institutions and practical activities: theoretical and applied problems of sociology and psychology of labor and professional education: materials of the Second International Scientific and Practical Conference. Prague. 2013: 75-83.

9. Yamaletdinova G.A., Makeeva V.S. Pushkina V.N. Efficiency of management of students 'cognitive Activity in the course of studying the discipline "Physical culture". Izvestiya Tul'skogo gosudarstvennogo universiteta. Fizicheskaya kul'tura. Sport. 2016; 3: 77-83 [In Russ.].

10. R Collins. "Interaction Ritual Chains". Princeton: Princeton University Press. 2004: 47-49. 11. Burgi F., Meyer U., Granacher U., Schindler C., Marques-Vidal P., Kriemler S., et. al. Relationship od physical activity with motor skills, aerobic fitness and body fat in preschool children: A cross-sectional and longitudinal study (Ballabeina). International Journal of Obesity (London). 2011; 35(7): 937-944.

12. Dreyyhaupt J., koch W., Wirt T., Schreiber A., Brandstetter S., Kesztyues D., et. al. Evaluation of a health promotion program in children: Study protocol and design of the clusterrandomized Baden-Wuerttemberg primary school study. BMC Public Health. 2012; 12(1): 157.

13. Ebenegger V., Marques-Vidal P., Kriemler S., Nydegger A., Zahner L., Niederer I., et. al. Differences in aerobic fitness and lifestyle characteristics in preschoolers according to their weight status and sports club participation. Obesity Facts. 2012; 5(1): 23-33.

14. Owen N., Healy G., Matthews C., Dunstan D. Too much sitting: The population health science of sedentary behavior. Exercise and Sport Sciences Reviews. 2010; 38(3): 105-113.

15. Ibrahhem T.O., Ajidua M.A., Dominic O.L. Quantification of leisure-time physical activity among universitystudents in south-west, Nigeria. Pedagogiko-psihologicheskie I medikobiologicheskie problemy fizicheskoj kul'tury I sporta = The Russian Journal of Physical Education and Sport. 2018; 13(1): 72-78. DOI: 10/14526/01_2018_285 [In Russ., In Engl.].

16. Evgeniya A. Raspopova, Yuliya A. Postolnik. Comparative analysis of dominant motives inducing students fromdifferent higher educational establishments to go in for physicalculture lessons. Pedagogiko-psihologicheskie I medikobiologicheskie problemy fizicheskoj kul'tury I sporta = The Russian Journal of Physical Education and Sport. 2018; 13(1): 125-132. DOI: 10/14526/01_2018_291

\section{Submitted: 25.01.2020}

\section{Author's information:}

Vera S. Makeeva - Doctor of Pedagogics, Professor, Russian State University of Physical Culture, Sport, Youth and Tourism, 105122, Russia, Moscow, Siren Boulevard, House 4, e-mail: vera1191@mail. $\underline{r u}$

Galina A. Yamaletdinova - Doctor of Pedagogics, Associate Professor, Liberal Arts University, 620049, Russia, Yekaterinburg, Studencheskaya Str, House 19,e-mail: yamalga@mail.ru

Kseniy E. Bruy - Candidate of Pedagogics, Moscow Region State University, 105005, Russia, Moscow, Radio Str., House 10, e-mail: ksenia tokareva19go@mail.ru 